\title{
Multicenter case-control study protocol of pneumonia etiology in children: Global Approach to Biological Research, Infectious diseases and Epidemics in Low-income countries (GABRIEL network)
}

Valentina Sanchez Picot ${ }^{1 \dagger}$, Thomas Bénet ${ }^{2,3 \dagger}$, Melina Messaoudi ${ }^{1}$, Jean-Noël Telles ${ }^{1}$, Monidarin Chou ${ }^{4}$, Tekchheng Eap ${ }^{5}$, Jianwei Wang ${ }^{6}$, Kunling Shen ${ }^{7}$, Jean-William Pape ${ }^{8}$, Vanessa Rouzier ${ }^{8}$, Shally Awasthi ${ }^{9}$, Nitin Pandey ${ }^{9}$, Ashish Bavdekar ${ }^{10}$, Sonali Sanghvi ${ }^{10}$, Annick Robinson ${ }^{11}$, Bénédicte Contamin ${ }^{12}$, Jonathan Hoffmann ${ }^{12}$, Maryam Sylla ${ }^{13}$, Souleymane Diallo ${ }^{14}$, Pagbajabyn Nymadawa ${ }^{15}$, Budragchaagiin Dash-Yandag ${ }^{16}$, Graciela Russomando ${ }^{17}$, Wilma Basualdo ${ }^{18}$, Marilda M Siqueira ${ }^{19}$, Patricia Barreto ${ }^{19}$, Florence Komurian-Pradel ${ }^{1}$, Guy Vernet ${ }^{1}$, Hubert Endtz' ${ }^{1}$ Philippe Vanhems ${ }^{2,3}$, Gláucia Paranhos-Baccalà ${ }^{*}$ and on behalf of the pneumonia GABRIEL network

\begin{abstract}
Background: Data on the etiologies of pneumonia among children are inadequate, especially in developing countries. The principal objective is to undertake a multicenter incident case-control study of $<5$-year-old children hospitalized with pneumonia in developing and emerging countries, aiming to identify the causative agents involved in pneumonia while assessing individual and microbial factors associated with the risk of severe pneumonia.

Methods/design: A multicenter case-control study, based on the GABRIEL network, is ongoing. Ten study sites are located in 9 countries over 3 continents: Brazil, Cambodia, China, Haiti, India, Madagascar, Mali, Mongolia, and Paraguay. At least 1,000 incident cases and 1,000 controls will be enrolled and matched for age and date. Cases are hospitalized children $<5$ years with radiologically confirmed pneumonia, and the controls are children without any features suggestive of pneumonia. Respiratory specimens are collected from all enrolled subjects to identify 19 viruses and 5 bacteria. Whole blood from pneumonia cases is being tested for 3 major bacteria. S. pneumoniae-positive specimens are serotyped. Urine samples from cases only are tested for detection of antimicrobial activity. The association between procalcitonin, C-reactive protein and pathogens is being evaluated. A discovery platform will enable pathogen identification in undiagnosed samples.

Discussion: This multicenter study will provide descriptive results for better understanding of pathogens responsible for pneumonia among children in developing countries. The identification of determinants related to microorganisms associated with pneumonia and its severity should facilitate treatment and prevention.
\end{abstract}

Keywords: Pneumonia, Children, Case-control, Etiology, Developing and emerging countries

\footnotetext{
* Correspondence: glaucia.baccala@fondation-merieux.org

'Equal contributors

${ }^{1}$ Emerging Pathogens Laboratory - Fondation Mérieux, Centre International de Recherche en Infectiologie (CIRI) Inserm U1111, CNRS UMR5308, ENS de

Lyon, UCBL1, 21, Avenue Tony Garnier, Lyon 69007, France

Full list of author information is available at the end of the article
} 


\section{Background}

With more than 120,000 million episodes occurring worldwide every year [1], pneumonia is the leading cause of child mortality from infectious diseases, accounting for an estimated 1 million deaths annually, and mainly afflicting children in developing countries according to Global Health Observatory [2]. Mortality attributed to pneumonia has decreased since 2000, but remains a major public health concern [3]. Improvements in medical care and the implementation of vaccination policies may have contributed to the decline in mortality [1]. However, data on the etiology and epidemiology of pneumonia in developing countries are still insufficient. Indeed, large studies that investigated the etiology of pneumonia in children were undertaken more than 20 years ago [4]. During this time, several epidemiological factors, such as human immunodeficiency virus (HIV) pandemic, Streptococcus pneumoniae and Haemophilus influenzae vaccine implementation, might have modified the global distribution of causative pathogens $[1,5,6]$. Moreover, the development of molecular techniques in the last few decades has led to the detection of numerous pathogens, mainly viruses $[7,8]$ (Figure 1).

The etiology of pneumonia could be either bacterial or viral.[9] The main known causative pathogens are Streptococcus pneumoniae [5,10]. Haemophilus influenzae [6], and respiratory syncitial virus (RSV) [11]. Interactions between viruses, bacteria and host are complex and remain poorly explored [12,13]. In outbreak situations, data on the spatial and temporal distribution of etiological agents are key to identification and control. Several predictors of pneumonia or severe pneumonia have been found $[14,15]$. However, the association with pneumonia etiology has not been fully investigated [15]. Indeed, the identification of factors strongly linked with complications or death could help in the development of appropriate therapeutic management strategies for these patients.

The purpose of the present work is to summarize the protocol of the multicenter incident case-control study of pneumonia in children less than 5 years of age, aiming to identify the etiological agents and related determinants involved in pneumonia. The countries participating in this study account for a significant part of the pneumonia burden in children worldwide. For example, India recorded around 35 million new cases of pneumonia in 2010, with the highest numbers of deaths in the world $(390,000)$, while China has 6 million cases and ranks fifth, with about 43,000 deaths annually [16]. Although pneumonia is still a major cause of mortality in other countries, observational data on pneumonia etiology are very sparse [16]. In Madagascar, for example, apart from earlier studies on influenza A and B viruses [17], to our knowledge, no other data are available on respiratory viruses and their transmission at the community level.

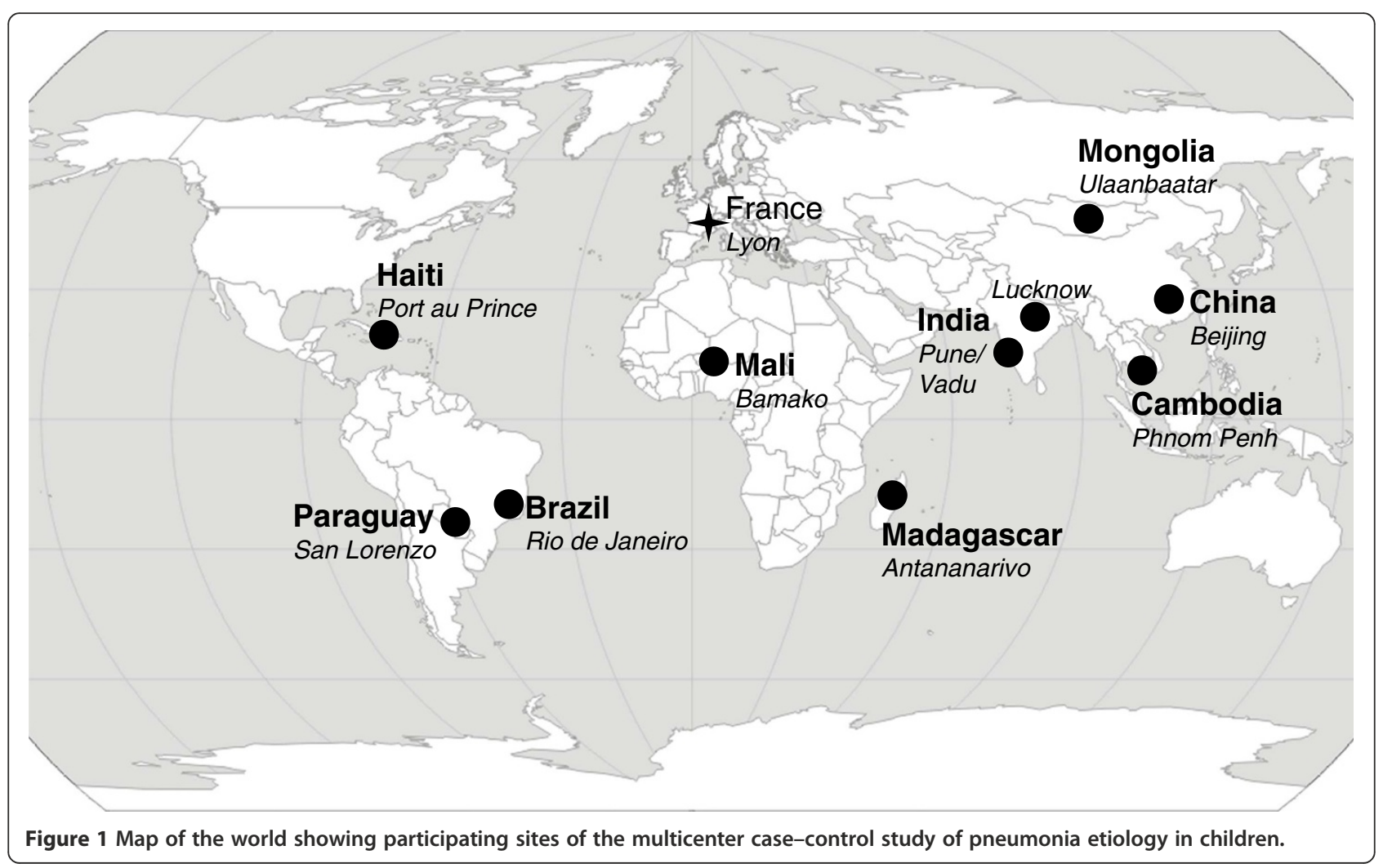




\section{Methods/Design Study objectives}

The study's primary objectives are to identify the causative agents involved in the onset of pneumonia in children and to assess individual and microbial factors associated with the risk of pneumonia, including severe pneumonia. Its secondary objectives are: 1 ) to examine the value of $\mathrm{C}$-reactive protein (CRP) and procalcitonin (PCT) in predicting the severity of pneumonia or infection by particular pathogens, 2) to estimate the involvement of etiological agents in pneumonia, and 3) to characterize new infectious agents or variants in pneumonia of unknown etiology.

\section{Study sites and design}

This prospective, hospital-based, multicenter case-control study is being conducted at 10 sites in 9 countries Brazil, Cambodia, China, Haiti, India (2 sites: Pune/Vadu and Lucknow), Madagascar, Mali, Mongolia, Paraguay on 3 continents. Enrollment of at least 100 incident cases and 100 controls during 12 months is planned for each participating site for a total sample of at least 2,000 subjects. The participating sites are members of the GABRIEL network of Fondation Mérieux [18]. Table 1 reports the demographic characteristics and burden of pneumonia in each participating country. Laboratory data are generated by local sites after reaching capacity, via technology transfer and training by the Emerging Pathogens Laboratory of Fondation Mérieux (Lyon, France).

\section{Study participants}

The study population, comprised of children under 5 years of age, complies with protocol definitions and inclusion criteria. Eligible patients are identified by study pediatricians at each participating site. Cases are defined by the following criteria: 1) Hospitalized patients aged between 2 months and 59 months, 2) Clinical features of pneumonia, as described below, 3) radiological confirmation of pneumonia on chest X-ray as per WHO guidelines [19], and 3) Informed consent statement signed by the children's parents or legal guardian. The exclusion criterion for cases are the following: presence of wheezing at auscultation, or minors whose parents or legal guardian declined to sign the informed consent statement.

Controls are defined by the following criteria: 1) Patients aged between 2 months and 59 months, 2) Hospitalized for surgery or in a routine outpatient practice environment, and 3) Informed consent statement signed by the children's parents or legal guardian. Exclusion criteria for the controls are: 1) Any symptom suggestive of respiratory illness, or 2) Minors whose parents or legal guardian decline to sign the informed consent statement. Cases and controls are matched for study site, age $( \pm 1$ year) and calendar date of hospital admission ( \pm 1 month).

\section{Definition of pneumonia}

Pneumonia cases are defined by the following:

- Cough and/or dyspnea, and

- Tachypnea, as defined by the World Health Organization (WHO) (in children between 2 and 12 months of age: breathing rate $\geq 50$ cycles per minute; in children between 12 months and 59 months of age: breathing rate $\geq 40$ cycles per minute) [20], and

- Absence of wheezing at auscultation, and

- First symptoms appearing within the last 14 days, and

- Radiological confirmation of pneumonia as per WHO guidelines [19].

\section{Data sources and quality control}

Research conduct and management are organized by the Emerging Pathogens Laboratory of Fondation Mérieux, primarily for evaluation and monitoring of the ethics, regulatory, clinical, laboratory and data generation components at each participating site. Tasks and responsibilities are based on standard research guidelines, including standard operating procedures. Data quality is monitored and evaluated by each site and by the Emerging Pathogens Laboratory for pooled data analysis. Demographic characteristics, underlying diseases, medical history, clinical examination at enrollment, radiological findings, vaccinations, and outcome are recorded prospectively for each patient on a standardized form (Table 2).

Data quality reporting is redacted for each site to ensure the conformity of all study data variables, it will detailed enrollment and case definition conformity, errors, and missing data $[21,22]$. This process will be applied to data analysis of each enrolled case and control. Each potential error is discussed, and a final rule applied. The principal investigator at each site is informed for queries regarding this quality assessment and is involved in resolution. A tracking system is applied to the process.

\section{Biological samples}

Samples are collected in the first 48 hours of the patient hospitalization. Nasal swabs/aspirates are collected from all pneumonia cases and controls. This collection procedure is performed by trained clinical staff, nurses and the principal investigator. Additional specimens are from cases only, including urine, whole blood and pleural effusions (Table 3). Antibiotic substances are detected in urine samples from all pneumonia cases to detect antibiotic usage history. Whole blood is collected and distributed in Ethylene-diamine-tetra-acetic acid (EDTA) vials for preservation and in dry tubes for serum specimens. EDTA-whole blood samples allow complete blood count, blood culture and real-time multiplex polymerase 
Table 1 Description of sites in multicenter case-control study of pneumonia etiology in children

\begin{tabular}{|c|c|c|c|c|c|c|c|c|c|c|c|c|}
\hline \multicolumn{6}{|c|}{ Study site characteristics } & \multicolumn{5}{|c|}{ Country characteristics } & \multicolumn{2}{|c|}{$\begin{array}{l}\text { Introduction } \\
\text { into national } \\
\text { immunization } \\
\text { program }^{a}\end{array}$} \\
\hline Hospital & Country & Town & $\begin{array}{l}\text { Related } \\
\text { research center }\end{array}$ & $\begin{array}{l}\text { Population } \\
\text { type }\end{array}$ & Climate & $\begin{array}{l}\text { Country } \\
\text { population, } \\
\text { millions } \\
\text { (year) }^{\mathrm{a}}\end{array}$ & $\begin{array}{l}\text { Population } \\
\text { living in } \\
\text { poverty, } \\
\% \text { (year) }^{\mathrm{a}}\end{array}$ & $\begin{array}{l}\text { Child } \\
\text { mortality } \\
\text { rate }(\% \circ)^{b}\end{array}$ & $\begin{array}{l}\text { Annual } \\
\text { pneumonia } \\
\text { cases }^{c}\end{array}$ & $\begin{array}{l}\text { Deaths } \\
\text { caused by } \\
\text { pneumonia } \\
\text { annuallyc }\end{array}$ & $\mathrm{PCV}^{\mathrm{d}}$ & $\begin{array}{l}\text { Hib }^{\mathrm{e}} \\
\text { vaccine }\end{array}$ \\
\hline $\begin{array}{l}\text { General Bonsucesso } \\
\text { Hospital }\end{array}$ & Brazil & $\begin{array}{l}\text { Rio de } \\
\text { Janeiro }\end{array}$ & $\begin{array}{l}\text { Fundaçao Oswaldo } \\
\text { Cruz }\end{array}$ & Urban & Rain/Dry & $199(2009)$ & $6.1(2009)$ & 16 & $1,497,706$ & 3,079 & 2010 & 1999 \\
\hline $\begin{array}{l}\text { National Pediatric } \\
\text { Hospital }\end{array}$ & Cambodia & Phnom Penh & $\begin{array}{l}\text { Phnom Pehn Faculty } \\
\text { of Pharmacy and } \\
\text { University of } \\
\text { Health Sciences }\end{array}$ & Urban & Rain/Dry & $14.9(2012)$ & $18.6(2009)$ & 43 & 373,583 & 2,101 & $\begin{array}{l}\text { Not } \\
\text { introduced }\end{array}$ & 2010 \\
\hline $\begin{array}{l}\text { Beijing Children's } \\
\text { Hospital }\end{array}$ & China & Beijing & $\begin{array}{l}\text { Chinese Academy } \\
\text { of Medical Sciences }\end{array}$ & Urban & $\begin{array}{l}\text { Four } \\
\text { seasons }\end{array}$ & $1,351(2012)$ & $11.8(2009)$ & 15 & $6,488,544$ & 43,089 & $\begin{array}{l}\text { Not } \\
\text { introduced }\end{array}$ & $\begin{array}{l}\text { Not } \\
\text { introduced }\end{array}$ \\
\hline Tent City Hospital $^{f}$ & Haïti & Port au Prince & GHESKIO Centers & Urban/rural & Rain/Dry & $10.2(2012)$ & $61.7(2001)$ & 70 & 345,081 & 4,090 & $\begin{array}{l}\text { Not } \\
\text { introduced }\end{array}$ & 2012 \\
\hline $\begin{array}{l}\text { KEM Hospital } \\
\text { Research Center } \\
\text { Shirdi Sai Baba } \\
\text { Rural Hospital }\end{array}$ & India & Pune/Vadu & $\begin{array}{l}\text { KEM Hospital Research } \\
\text { Center Sai Baba } \\
\text { Rural Hospital }\end{array}$ & Urban/rural & $\begin{array}{l}\text { Three } \\
\text { seasons }\end{array}$ & 1,236.7 (2012) & $32.7(2010)$ & 61 & $35,361,230$ & 388,144 & $\begin{array}{l}\text { Not } \\
\text { introduced }\end{array}$ & 2011 \\
\hline $\begin{array}{l}\text { Chatrapati Shahuji } \\
\text { Maharaj University } \\
\text { Hospital }\end{array}$ & India & Lucknow & $\begin{array}{l}\text { Chatrapati Shahuji } \\
\text { Maharaj University }\end{array}$ & Urban/rural & Rain/Dry & 1,236.7 (2012) & $32.7(2010)$ & 61 & $35,361,230$ & 388,144 & $\begin{array}{l}\text { Not } \\
\text { introduced }\end{array}$ & 2011 \\
\hline $\begin{array}{l}\text { Hôpital Femme- } \\
\text { Mere-Enfant }\end{array}$ & Madagascar & Antananarivo & $\begin{array}{l}\text { Centre Charles } \\
\text { Mérieux }\end{array}$ & Urban & Rain/Dry & $22.3(2012)$ & $81.3(2010)$ & 62 & $1,051,407$ & 2,638 & 2011 & 2008 \\
\hline $\begin{array}{l}\text { Gabriel Toure } \\
\text { Hospital }\end{array}$ & Mali & Bamako & $\begin{array}{l}\text { Centre Charles } \\
\text { Mérieux }\end{array}$ & Urban/rural & Rain/Dry & 14.9 (2012) & 50.4 (2010) & 176 & 932,894 & 7,893 & 2008 & 2011 \\
\hline $\begin{array}{l}\text { Bayanzurkh District } \\
\text { General Hospital }\end{array}$ & Mongolia & Ulaanbaatar & $\begin{array}{l}\text { Mongolian Academy } \\
\text { of Medical Sciences }\end{array}$ & Urban & $\begin{array}{l}\text { Four } \\
\text { seasons }\end{array}$ & 2.8 (2012) & $27.4(2012)$ & 31 & 60,292 & 332 & $\begin{array}{l}\text { Not } \\
\text { introduced }\end{array}$ & 2008 \\
\hline $\begin{array}{l}\text { Pediatric General } \\
\text { Hospital, Niños } \\
\text { de Acosta Ñu }\end{array}$ & Paraguay & San Lorenzo & $\begin{array}{l}\text { Research Institute } \\
\text { of Health }\end{array}$ & Urban/rural & Rain/Dry & 6.7 (2009) & 7.2 (2012) & 22 & 139,661 & 368 & 2012 & 2002 \\
\hline $\begin{array}{l}\text { anternational Vaccine } A \\
\text { 2013. www.jhsph.edu/iv } \\
\text { b'World Bank Group: htt } \\
\text { 'Data from Rudan I, O'B } \\
\text { countries. J Glob Health } \\
\text { dPneumococcal conjug } \\
\text { e Haemophilus influenzae }\end{array}$ & $\begin{array}{l}\text { eess Center (IVA } \\
\text { c/vims.html. } \\
\text { //povertydata.w } \\
\text { en KL, Nair H, et } \\
\text { 013;3:010401. } \\
\text { vaccine. } \\
\text { ype B. }\end{array}$ & $\begin{array}{l}\text { C), Johns Hopkins } \\
\text { orldbank.org. } \\
\text { al. Epidemiology }\end{array}$ & 5 Bloomberg School of Publ & lic Health. Vac & cine Informa & Management SY & ystem (VIMS) G & lobal Vaccine & Introduction Re & $\begin{array}{l}\text { eport, October } \\
\text { ctors and causat }\end{array}$ & 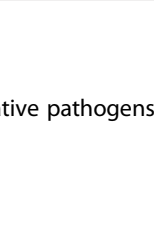 & for 192 \\
\hline
\end{tabular}


Table 2 Individual questionnaire among cases and controls in multicenter case-control study of pneumonia etiology in children

\begin{tabular}{|c|c|c|}
\hline \multirow{2}{*}{$\begin{array}{l}\text { Category } \\
\text { General }\end{array}$} & \multicolumn{2}{|l|}{ Information } \\
\hline & Hospital & Country \\
\hline Demographic & Gender & Date of birth \\
\hline \multirow{4}{*}{$\begin{array}{l}\text { Underlying } \\
\text { diseases }\end{array}$} & Heart disease & Lung disease \\
\hline & Tuberculosis & Asthma \\
\hline & Pneumonia & HIV infection \\
\hline & Others & \\
\hline \multirow[t]{3}{*}{ Medical history } & $\begin{array}{l}\text { Contact with } \\
\text { tuberculosis }\end{array}$ & Previous influenza \\
\hline & $\begin{array}{l}\text { Prior treatment } \\
\text { with antibiotics }\end{array}$ & Prior treatment for fever \\
\hline & $\begin{array}{l}\text { Date of first } \\
\text { symptoms }\end{array}$ & \\
\hline \multirow{14}{*}{$\begin{array}{l}\text { Clinical } \\
\text { examination } \\
\text { at enrollment }\end{array}$} & Weight & Height \\
\hline & Arm circumference & Temperature \\
\hline & Blood pressure & Breathing rate \\
\hline & $\begin{array}{l}\text { Arterial oxygen } \\
\text { saturation }\end{array}$ & Cough \\
\hline & Dyspnea & Lower chest indrawing \\
\hline & Cyanosis & Pulmonary crackles \\
\hline & $\begin{array}{l}\text { Dullness to } \\
\text { percussion of } \\
\text { the thorax }\end{array}$ & Rhonchi \\
\hline & Wheezing & Rasping \\
\hline & $\begin{array}{l}\text { Diminished } \\
\text { breathing sounds }\end{array}$ & Convulsions \\
\hline & $\begin{array}{l}\text { Other pulmonary } \\
\text { signs and symptoms }\end{array}$ & Rhinopharyngitis \\
\hline & $\begin{array}{l}\text { Prostration } \\
\text { or lethargy }\end{array}$ & Conjunctivitis \\
\hline & Otitis & Inability to drink \\
\hline & Skin rash & Diarrhea \\
\hline & Vomiting & Other signs \\
\hline Radiological & Opacification & Abscess \\
\hline findings & Interstitial syndrome & Pneumothorax \\
\hline (cases only) & Alveolar infiltrate & Parenchymatous infiltrate \\
\hline $\begin{array}{l}\text { Vaccination (dates, } \\
\text { number of doses) }\end{array}$ & $\begin{array}{l}\text { Pneumococcal } \\
\text { conjugate vaccine } \\
\text { Influenza vaccine }\end{array}$ & $\begin{array}{l}\text { Diphtheria, tetanus, pertussis, } \\
\text { hepatitis B, and Haemophilus } \\
\text { influenzae type B vaccine }\end{array}$ \\
\hline \multirow[t]{4}{*}{$\begin{array}{l}\text { During } \\
\text { hospital stay }\end{array}$} & $\begin{array}{l}\text { Antibiotics (dates, } \\
\text { doses, duration) }\end{array}$ & Oxygen therapy \\
\hline & Other drugs & Death \\
\hline & Acute complications & Cause of death \\
\hline & Recovery & \\
\hline
\end{tabular}

Table 3 Laboratory tests in multicenter case-control study of pneumonia etiology in children

\begin{tabular}{|c|c|c|}
\hline Samples & Population & Analyses \\
\hline Nasal swab/aspirate & Cases and controls & $\begin{array}{l}\text { Molecular detection of } \\
\text { viruses and bacteria } \\
\text { S. pneumoniae typing }\end{array}$ \\
\hline Pleural effusion & Cases (if pleuritis) & $\begin{array}{l}\text { Molecular detection of } \\
\text { viruses and bacteria } \\
\text { S. pneumoniae typing }\end{array}$ \\
\hline \multirow[t]{4}{*}{ Whole blood } & Cases & $\begin{array}{l}\text { Molecular detection of } \\
\text { viruses and bacteria }\end{array}$ \\
\hline & & S. pneumoniae typing \\
\hline & & Blood culture \\
\hline & & Blood count \\
\hline \multirow[t]{2}{*}{ Serum } & Cases & C-reactive protein \\
\hline & & Procalcitonin \\
\hline Urine & Cases & Broad antibiotic detection \\
\hline
\end{tabular}

chain reaction (PCR) assay for the identification of Staphylococcus aureus, Streptococcus pneumoniae and Haemophilus influenzae type B. CRP and PCT are measured quantitatively in serum. Respiratory specimens (nasal swabs/aspirates and pleural effusions) will permit to identify viruses and bacteria by real-time multiplex PCR assay with a panel of 19 viruses and 5 bacteria (FTD respiratory pathogens 21 PLUS (Fast-track Diagnostic, Luxemburg). The pathogens targeted are: influenza A, H1N1, influenza B, coronavirus 229E, coronavirus OC43, coronavirus NL63, coronavirus HKU1, parainfluenza virus 1 , parainfluenza virus 2 , parainfluenza virus 3 , parainfluenza virus 4 , human metapneumoviruses $\mathrm{A}$ and $\mathrm{B}$, rhinovirus, RSVs A and B, adenovirus, enterovirus, parechovirus, bocavirus), Mycoplasma pneumoniae, Chlamydia pneumoniae, S. aureus, S. pneumoniae, and H. influenzae type B. S. pneumoniae-positive specimens are serotyped with a multiplex real-time PCR method that detects 29 different serotypes (1, 3, 4, 5, 6A/B, 7C, 7F, 8, 9V, 10A, 11A, 12F, 14, 15A, 15B/ C, 16F, 17F, Sg18C, 19A, 19F, 20, 22F, 23F, 31, 33F, 34, 35B, 35F, 38 and Lyt A). A centralized, blinded PCR respiratory quality control panel is also provided to all sites to ensure procedure validation on site before specimens are processed locally. The control panel is processed every 3 months at each laboratory site. Each laboratory has to successfully test the control panels to proceed with the study.

\section{Potential bias}

Because the study concerns hospitalized pneumonia cases, the magnitude of putative selection bias according to disease severity will be evaluated for cases and controls. Control charts will detect evolving selection bias over time at particular sites [21]. Patients' characteristics and the clinical presentation of pneumonia cases will be described and compared between sites. Precise evaluation of diagnostic 
criteria and standardized biological tests with central analysis should reduce misclassification bias. A flow chart describing the quality of case enrollment and follow-up is constructed by site and for pooled populations. Based on past experiences in multicenter pneumonia studies, particular attention will be paid to standardization of case definition $[4,23]$. Moreover, heterogeneity of the raw data will be compared between sites. This process will precisely define the population that is enrolled in the pooled analysis, according to data validity and population homogeneity. Multivariate analysis (described above) will take the main confounding factors into account.

\section{Study size power calculation}

With 100 cases and 100 controls per site, analysis in a particular site will have $80 \%$ power to detect odds ratios $(\mathrm{OR}) \geq 3$ with prevalence of exposure $\geq 20 \%$ for the controls, whatever the prevalence of exposure associated with a case. With 1,000 cases and 1,000 controls, overall analysis will have $90 \%$ power to detect OR $\geq 2$ with exposure in controls $\geq 5 \%$, whatever the prevalence of exposure associated with a case. Therefore, the study will include at least 2,000 patients; at least 100 cases and 100 controls enrolled at each participating site.

\section{Statistical methods}

An anonymous database will be built and analyzed. Quantitative variables will be described and categorized according to their distribution in the study population. The proportion of missing data will be described for all variables, and the mechanism of missing data will be researched; a multiple imputation process of missing data will be implemented, if necessary. Descriptive analysis will address each covariate for the entire population, and stratified by site. If multiple microorganisms are detected, typology of co-infections will be developed. Co-infections/colonization will be reported by site, patients' characteristics and time.

Patients' characteristics and microbiological data on cases and controls will be compared. Mixed effects logistic univariate and multivariate regression modeling will be applied to assess factors associated with pneumonia or infection by particular pathogens. These models will take into account heterogeneity in baseline risk between sites and countries as well as the nested nature of the data. Indeed, microbial agents are nested in patients because they could be infected by several agents; patients are nested in sites and countries. Other analysis will focus on factors associated with co-infection, for each possible pair or trio of microorganisms. Individual and microbial factors linked with the risk of severe disease or death will be analyzed by survival models, if applicable. Sensitivity, specificity and predictive values will be calculated to research the value of CRP and PCT in predicting the severity of pneumonia or infection by particular pathogens. Complementary methods and stratified analyses will be deployed, if necessary, to study the distribution of the causative agents of pneumonia according the underlying medical condition such as HIV for example.

\section{Ethics and confidentiality}

The study protocol, informed consent statement, clinical research form, any amendments and all other study documents have been submitted to and approved by the institutional ethics committee of each site: Brazil (Conselho Nacional de Saúde, Comissão Nacional de Ética em Pesquisa, Ministerio da Saúde), China (National Ethics Committee, Ministry of Health, Cambodia (National Ethics Commitee for Health Research, Ministry of Health), Haiti (Comité des Droits Humains des Centres GHESKIO, Comité National d'Ethique, Ministère de la Santé Publique et de la Population, and Institutional Review Board of Weill Cornell Medical College), India Lucknow center (Institutional Ethics Committee, Chhatrapati Shahuji Maharaj Medical University, Uttar Pradesh), India Pune (Ethics Commity at KEM hospital research centre), Madagascar (Comité d'Ethique, Ministère de la Santé Publique), Mali (Comité national d'éthique pour la santé et les sciences de la vie), Mongolia (Ethical committee for medical research), and Paraguay (Comité de Ética en Investigación del Instituto de Investigaciones en Ciencias de la Salud de la Universidad Nacional de Asunción).

\section{Discussion}

Multicenter pneumonia study analysis will be reported for publication in 2015. Individual site analysis, focusing on particular interests, will also be described and published at a later date.

Study analysis will generally focus on the description of causative pathogens at the onset of pneumonia for the entire population and by country site. Several studies have already investigated the etiology of pneumonia [24]. However, they were limited by either unicentric study design [14], focused on a particular pathogen [25], lacked a control group [26], or employed diagnosis techniques with limited sensitivity [24]. Many reports came from highincome countries, in highly-selected populations, such as patients with pneumonia requiring intensive care unit stay [27]. Data are lacking on pneumonia etiology in developing countries based on worldwide distribution of study sites. A better understanding of pathogens causing pneumonia in children should contribute to improved preventive - through implementation of vaccine policies and therapeutic management, ultimately leading to reduced morbidity and mortality of pneumonia in children. Moreover, CRP combined with PCT has demonstrated value in predicting pneumonia in adults, but interest in pediatric populations as not been well demonstrated [28,29]. 
Thus, our study should provide new data on the following questions: What are the viral and bacterial etiological agents of pneumonia in children under 5 years of age in developing and emerging countries? What is their seasonal distribution? What are the circulating pneumococcal serotypes? What is the distribution of coinfections? What is the clinical profile of co-infected patients? Are CRP and PCT predictive markers of pneumonia etiology? Which pathogen is presented in samples without any etiology?

Several study weaknesses should be considered, including bias, confounders and statistical power. Firstly, potential selection bias with different mechanisms of selection between sites might occur. Indeed, a particular site might include cases according to a definition that does not exactly conform to standardized case definition, as with the controls. Another example might be the selection of subjects due to local clinical practices or field experiences. These different mechanisms of selection could jeopardize data interpretation, by site and pooled analysis [30]. Some subjects' results might be excluded from the overall analysis. Secondly, external validity could be questioned by site compared to the country population to assess representativeness of the study population, and compared with the world population for pooled analysis [30]. Thirdly, limited information might be available on exposures preceding pneumonia occurrence. Also, some confounding related to nutrition or parental history factors, will be missing at the individual level. However, the geographical (i.e., rainfall, temperature) and socio-cultural (i.e., type of population) context as well as study site and local health care system characteristics will be described [31]. Finally, the quality and distribution of variables will limit some statistical analyses, with an impact on study power. Thus, multiple imputations as assumption checking before modeling will also be a key issue before running statistical analysis.

The study's main strength is the prospective collection of multiple biological samples that should permit the diagnosis of etiological agents involved in pneumonia as well as the importance of colonization by other microbial agents. Another advantage is the multicenter study design that will permit the description of various etiologies of pneumonia in study-related regions of the world [18]. It is noteworthy that the two most populous countries in the world, which represent a large burden of pneumonia incidence and mortality worldwide - China and India - are part of the study [16]. The results of our multicenter pneumonia study could be possibly compared with those of other contemporary pneumonia investigations. In this regard, the ongoing Pneumonia Etiology Research for Child Health $(\mathrm{PERCH})$ study will be particularly informative
[32]. Indeed, study design, case definition, molecular techniques and biological samples, while not identical, are not very different between the two multicenter works $[33,34]$. PERCH is larger than the present study, but countries such as India and China are not participating in it while they are included in our multicenter pneumonia investigation. Also, comparative analyses might be considered as a perspective that could offer new insights into pneumonia etiologies worldwide.

\section{Conclusion}

In conclusion, our multicenter pneumonia study will detail pneumonia etiologies among children in 9 countries on 3 continents. The results could be helpful not only in improving individual care but also in formulating appropriate public health policies [35].

\section{Abbreviations}

CRP: C-reactive protein; EDTA: Ethylene-diamine-tetra-acetic acid; GABRIEL: Global Approach to Biological Research on infectious, Epidemics in Low-income countries; HIV: Human immunodeficiency virus; OR: Odds ratio; PERCH: Pneumonia Etiology Research for Child Health; PCR: polymerase chain reaction; PCT: Procalcitonin; RSV: Respiratory syncytial virus; WHO: World Health Organization.

\section{Competing interests}

The authors declare that they have no competing interests.

\section{Authors' contributions}

All authors designed and co-authored the protocol. GP-B, TB, VP, and PV drafted the initial manuscript. All authors read, commented on and approved the final manuscript version.

\section{Acknowledgements}

We thank specially the GABRIEL pneumonia experts: Ron Dagan from Pediatric Infectious Disease Unit, Soroka University Medical Center, Beer-Sheva, Israel; Samir K Saha from Department of Microbiology, Bangladesh Institute of Child Health, Dhaka Shishu Hospital, Bangladesh and Werner Albrich from Kantonspital Aarau AG, Bereich Medizin, Switzerland Manuscript editing by Ovid Da Silva is acknowledged

This protocol has been developped on behalf of members of the GABRIEL network (Global Approach to Biological Research, Infectious diseases and Epidemics in Low-income countries, http://gabriel.globe-network.org/).

\section{Funding}

This study has been externally funded by the Fondation Mérieux and GABRIEL network.

\section{Author details}

${ }^{1}$ Emerging Pathogens Laboratory - Fondation Mérieux, Centre International de Recherche en Infectiologie (CIRI) Inserm U1111, CNRS UMR5308, ENS de Lyon, UCBL1, 21, Avenue Tony Garnier, Lyon 69007, France. ${ }^{2}$ Infection Control and Epidemiology Unit, Edouard Herriot Hospital, Hospices Civils de Lyon, Lyon, France. ${ }^{3}$ Epidemiology and Public Health Unit, University of Lyon 1, Lyon, France. ${ }^{4}$ Faculty of Pharmacy, University of Health Sciences, Phnom Penh, Cambodia. ${ }^{5}$ Department of Pneumology, National Pediatric Hospital, Phnom Penh, Cambodia. ${ }^{6} \mathrm{MOH}$ Key Laboratory of Systems Biology of Pathogens and Dr. Christophe Mérieux Laboratory, IPB, CAMS-Fondation Mérieux, Institute of Pathogen Biology (IPB), Chinese Academy of Medical Sciences (CAMS) \& Peking Union Medical College), Beijing, China. ${ }^{7}$ Key Laboratory of Major Diseases in Children and National Key Discipline of Pediatrics (Capital Medical University), Ministry of Education, Beijing Pediatric Research Institute, Beijing Children's Hospital, Capital Medical University, Beijing, China. ${ }^{8} \mathrm{GHESKIO}$ (Groupe Haïtien d'Etude du Sarcome de Kaposi et des Infections Opportunistes) Centers, Port au Prince, Haiti. ${ }^{9}$ Chatrapati Shahuji Maharaj University, Lucknow, India. ${ }^{10}$ KEM Hospital Research Center, Pune, India. ${ }^{11}$ Hôpital Femme-Mère-Enfant, 
Antananarivo, Madagascar. ${ }^{12}$ Fondation Mérieux, Centre d'Infectiologie Charles Mérieux (CICM), Antananarivo, Madagascar. ${ }^{13}$ Gabriel Touré Hospital, Bamako, Mali. ${ }^{14}$ Centre d'Infectiologie Charles Mérieux (CICM), Bamako, Mali. ${ }^{15}$ Mongolian Academy of Medical Sciences, Ulaanbaatar, Mongolia. ${ }^{16}$ Bayanzurkh District General Hospital, Ulaanbaatar, Mongolia. ${ }^{17}$ Research Institute of Health, Asuncion, Paraguay. ${ }^{18}$ Hospital Pediátrico "Niños de Acosta Ñu", San Lorenzo, Paraguay. ${ }^{19}$ Respiratory virus Laboratory, Oswaldo Cruz Foundation, Hospital Bonsucesso, Rio de Janeiro, Brazil.

\section{Received: 11 August 2014 Accepted: 17 November 2014}

Published online: 10 December 2014

\section{References}

1. Walker CLF, Rudan I, Liu L, Nair H, Theodoratou E, Bhutta ZA, O'Brien KL, Campbell H, Black RE: Global burden of childhood pneumonia and diarrhoea. Lancet 2013, 381:1405-1416.

2. Global Health Observatory Data Repository [http://apps.who.int/gho/data/ view.main.CM100WORLD-CH9?lang=en]

3. Black RE, Cousens S, Johnson HL, Lawn JE, Rudan I, Bassani DG, Jha P, Campbell H, Walker CF, Cibulskis R, Eisele T, Liu L, Mathers C, Child Health Epidemiology Reference Group of WHO and UNICEF: Global, regional, and national causes of child mortality in 2008: a systematic analysis. Lancet 2010, 375:1969-1987.

4. Selwyn BJ: The epidemiology of acute respiratory tract infection in young children: comparison of findings from several developing countries. Coordinated Data Group of BOSTID Researchers. Rev Infect Dis 1990, 12(Suppl 8):S870-S888.

5. O'Brien KL, Wolfson L, Watt JP, Henkle E, Deloria-Knoll M, McCall N, Lee E, Mulholland K, Levine OS, Cherian T, Hib and Pneumococcal Global Burden of Disease Study Team: Burden of disease caused by Streptococcus pneumoniae in children younger than 5 years: global estimates. Lancet 2009, 374:893-902.

6. Watt JP, Wolfson LJ, O'Brien KL, Henkle E, Deloria-Knoll M, McCall N, Lee E, Levine OS, Hajjeh R, Mulholland K, Cherian T: Burden of disease caused by Haemophilus influenzae type $b$ in children younger than 5 years: global estimates. Lancet 2009, 374:903-911.

7. Van den Hoogen BG, de Jong JC, Groen J, Kuiken T, de Groot R, Fouchier RAM, Osterhaus ADME: A newly discovered human pneumovirus isolated from young children with respiratory tract disease. Nat Med 2001, 7:719-724.

8. Woo PCY, Lau SKP, Chu C, Chan K, Tsoi H, Huang Y, Wong BHL, Poon RWS, Cai JJ, Luk W, Poon LLM, Wong SSY, Guan Y, Peiris JSM, Yuen K: Characterization and Complete Genome Sequence of a Novel Coronavirus, Coronavirus HKU1, from Patients with Pneumonia. J Virol 2005, 79:884-895.

9. Ruuskanen O, Lahti E, Jennings LC, Murdoch DR: Viral pneumonia. Lancet 2011, 377:1264-1275.

10. Robinson KA, Baughman W, Rothrock G, Barrett NL, Pass M, Lexau C, Damaske B, Stefonek K, Barnes B, Patterson J, Zell ER, Schuchat A, Whitney CG, Active Bacterial Core Surveillance (ABCs)/Emerging Infections Program Network: Epidemiology of invasive streptococcus pneumoniae infections in the united states, 1995-1998: Opportunities for prevention in the conjugate vaccine era. JAMA 2001, 2001(285):1729-1735.

11. Nair H, Nokes DJ, Gessner BD, Dherani M, Madhi SA, Singleton RJ, O'Brien KL, Roca A, Wright PF, Bruce N, Chandran A, Theodoratou E, Sutanto A, Sedyaningsih ER, Ngama M, Munywoki PK, Kartasasmita C, Simões EAF, Rudan I, Weber MW, Campbell H: Global burden of acute lower respiratory infections due to respiratory syncytial virus in young children: a systematic review and meta-analysis. Lancet 2010, 375:1545-1555.

12. Breese Hall C, Powell KR, Schnabel KC, Gala CL, Pincus PH: Risk of secondary bacterial infection in infants hospitalized with respiratory syncytial viral infection. J Pediatr 1988, 113:266-271.

13. Scheiblauer $H$, Reinacher M, Tashiro M, Rott R: Interactions between Bacteria and Influenza A Virus in the Development of Influenza Pneumonia. J Infect Dis 1992, 166:783-791.

14. Muhe L, Lulseged S, Mason KE, Simoes EA: Case-control study of the role of nutritional rickets in the risk of developing pneumonia in Ethiopian children. Lancet 1997, 349:1801-1804.

15. Wonodi CB, Deloria-Knoll M, Feikin DR, DeLuca AN, Driscoll AJ, Moïsi JC, Johnson HL, Murdoch DR, O'Brien KL, Levine OS, Scott JAG: Evaluation of risk factors for severe pneumonia in children: the Pneumonia Etiology research for Child Health Study. Clin Infect Dis 2012, 54:S124-S131.

16. Rudan I, O'Brien KL, Nair H, Liu L, Theodoratou E, Qazi S, Luksic I, Fischer Walker CL, Black RE, Campbell H: Epidemiology and etiology of childhood pneumonia in 2010: estimates of incidence, severe morbidity, mortality, underlying risk factors and causative pathogens for 192 countries. J Glob Health 2013, 3:010401.

17. Ravaoarinoro M, Razafimihery J, Razanamparany $M$, Coulanges $P$. Viral etiology of acute respiratory infections in Madagascan children. Arch Inst Pasteur Madagascar 1986, 52:147-155.

18. Komurian-Pradel F, Grundmann N, Siqueira MM, Chou M, Diallo S, Mbacham W, Paboriboune P, Russomando G, Nymadawa P, Sarkis DK, Samison LH, Wang J, Pape JW, Paranhos-Baccalà G, Vernet G: Enhancing research capacities in infectious diseases: The GABRIEL network, a joint approach to major local health issues in developing countries. Clin Epidemiol Glob Health 2013, 1:40-43.

19. Cherian T, Mulholland EK, Carlin JB, Ostensen H, Amin R, de Campo M, Greenberg D, Lagos R, Lucero M, Madhi SA, O'Brien KL, Obaro S, Steinhoff $M C$ : Standardized interpretation of paediatric chest radiographs for the diagnosis of pneumonia in epidemiological studies. Bull World Health Organ 2005, 83:353-359.

20. Ayieko P, English M: Case Management of Childhood Pneumonia in Developing Countries. Pediatr Infect Dis J 2007, 26:432-440.

21. Harel O, Schisterman EF, Vexler A, Ruopp MD: Monitoring quality control: can we get better data? Epidemiol Camb Mass 2008, 19:621-627.

22. John Roberts R, Musick BS, Olley B, Hall KS, Hendrie HC, Oyediran ABOO: Data management in a longitudinal cross-cultural study. Stat Med 2000, 19:1645-1649.

23. Scott JAG: The global epidemiology of childhood pneumonia 20 years on. Bull World Health Organ 2008, 86:494-496.

24. Gilani Z, Kwong YD, Levine OS, Deloria-Knoll M, Scott JAG, O'Brien KL, Feikin DR: A Literature Review and Survey of Childhood Pneumonia Etiology Studies: 2000-2010. Clin Infect Dis 2012, 54:S102-S108.

25. Eun BW, Kim NH, Choi EH, Lee HJ: Mycoplasma pneumoniae in Korean children: the epidemiology of pneumonia over an 18-year period. $J$ Infect 2008, 56:326-331.

26. Arifeen SE, Saha SK, Rahman S, Rahman KM, Rahman SM, Bari S, Naheed A, Mannan I, Seraji MHR, Ahmed NU, Hassan MS, Huda N, Siddik AU, Quasem I, Islam M, Fatima K, Al-Emran H, Brooks WA, Baqui AH, Breiman RF, Sack D, Luby SP: Invasive pneumococcal disease among children in rural Bangladesh: results from a population-based surveillance. Clin Infect Dis Am 2009, 48:S103-S113.

27. Foglia $E$, Meier $M D$, Elward A: Ventilator-associated pneumonia in Neonatal and Pediatric Intensive Care Unit Patients. Clin Microbiol Rev 2007, 20:409-425.

28. Khan DA, Rahman A, Khan FA: Is procalcitonin better than C-reactive protein for early diagnosis of bacterial pneumonia in children? J Clin Lab Anal 2010, 24:1-5.

29. Van Vugt SF, Broekhuizen BDL, Lammens C, Zuithoff NPA, de Jong PA, Coenen S, leven M, Butler CC, Goossens H, Little P, Verheij TJM, on behalf of the GRACE consortium: Use of serum $C$ reactive protein and procalcitonin concentrations in addition to symptoms and signs to predict pneumonia in patients presenting to primary care with acute cough: diagnostic study. BMJ 2013, 346:f2450-f2450.

30. Grimes DA, Schulz KF: Bias and causal associations in observational research. Lancet 2002, 359:248-252.

31. Lanata CF, Rudan I, Boschi-Pinto C, Tomaskovic L, Cherian T, Weber M, Campbell H: Methodological and quality issues in epidemiological studies of acute lower respiratory infections in children in developing countries. Int J Epidemiol 2004, 33:1362-1372.

32. Levine OS, O'Brien KL, Deloria-Knoll M, Murdoch DR, Feikin DR, DeLuca AN, Driscoll AJ, Baggett HC, Brooks WA, Howie SRC, Kotloff KL, Madhi SA, Maloney SA, Sow S, Thea DM, Scott JA: The Pneumonia etiology research for child health project: a 21st Century Childhood Pneumonia Etiology Study. Clin Infect Dis 2012, 54:S93-S101.

33. Scott JAG, Wonodi C, Moïsi JC, Deloria-Knoll M, DeLuca AN, Karron RA, Bhat N, Murdoch DR, Crawley J, Levine OS, O'Brien KL, Feikin DR: The definition of Pneumonia, the assessment of severity, and clinical standardization in the pneumonia etiology research for child health study. Clin Infect Dis 2012, 54:S109-S116. 
34. Bhat N, O'Brien KL, Karron RA, Driscoll AJ, Murdoch DR: Use and evaluation of molecular diagnostics for pneumonia etiology studies. Clin Infect Dis 2012, 54:S153-S158.

35. Bhutta ZA, Das JK, Walker N, Rizvi A, Campbell H, Rudan I, Black RE, Lancet Diarrhoea and Pneumonia Interventions Study Group: Interventions to address deaths from childhood pneumonia and diarrhoea equitably: what works and at what cost? Lancet 2013, 381:1417-1429.

doi:10.1186/s12879-014-0635-8

Cite this article as: Picot et al.: Multicenter case-control study protocol of pneumonia etiology in children: Global Approach to Biological Research, Infectious diseases and Epidemics in Low-income countries

(GABRIEL network). BMC Infectious Diseases 2014 14:635.

\section{Submit your next manuscript to BioMed Central and take full advantage of:}

- Convenient online submission

- Thorough peer review

- No space constraints or color figure charges

- Immediate publication on acceptance

- Inclusion in PubMed, CAS, Scopus and Google Scholar

- Research which is freely available for redistribution 